\title{
Reason and Narration with Ibn Rushd (Averroes)
}

\author{
Mohammad Ali Khattab \\ Ph.D. Comparative Religion - Associated Prof. \\ Faculty of Engineering and Technology - Al-Balqa Applied University \\ Amman - Jordan
}

\begin{abstract}
Ibn Rushd was distinguished by his bewildering personality, stemming from being a jurist and theologist, a philosopher and physician, and an astronomer. When researching his writings, we found that he encourages a lot of reason, and puts aside everything related to revelation, at other times, you find him defending Revelation and does not care about the mind, and you see him attacking the Asha'ries. In some cases, he defends them in other places, and in some cases, he adopts the views of the predecessor, making him a collector of all contradictions. However, the beholder in his biography and history knows that he went through several stages, stamped with jurisprudential stability, moderation in judging the opponents, and a victory for the doctrine of Tafweedh.
\end{abstract}

\section{Who is Ibn Rushd?}

\section{PREFACE}

Before talking about Ibn Rushd attitude on reason and narration, it's worthy to introduce him: About his life and philosophy in order to study the circumstances in which he grew up until he became one of the masters of philosophy which exposed him to torment and suffering and displacement, and even he was accused of atheism heresy !.

He is, AbulWaleed bin Ahmad Mohammad bin Ahmad bin Rushd, was born in Cordoba in 520 H, - 1026 A.D. He grew up liking science (knowledge) and scientists (scholars) under the care of his father who was one of the major scholars of Cordoba and its province. Since his childhood, he adored study of medicine and Sharia law, and looked into metaphysical studies, so he showed remarkable intelligence. The most obscure matter is the ambiguity of where and who is his tutor of metaphysical sciences? Some believe that Ibn Bajah, the outstanding philosopher, tutored him but the reality denies this because Ibn Bajah died in 1138 A.D while Ibn Rushd was only 12 years old, this makes it impossible to study philosophy at this early age. On the contrary, he was during this period studying Sharia principles and sciences such as jurisdiction and reasoning under the supervision of his father. Others believe that Ibn Tufail tutored him, but history proves that Ibn Tufail did not know Ibn Rushd until he became famous and known everywhere as a philosopher and physician. This proved in an incident, when he entered to Sultan Yusuf bin Yaqub for the first time while Ibn Tufail was present in the sitting, Ibn Rushd said: (When I entered at Amirul Mumeneen Ibn Yaqub, I found him with Abu Bakr bin Tufail, meanwhile Ibn Tufail praised me and mentioned my family and even speaking things beyond virtues I really deserve). This proves that Ibn Tufail only new Ibn Rushd after he had become famous, and did not know him before though he might have taught him.

This proves historically that Ibn Rushd did not receive his philosophy education from Ibn Tufail or Ibn Bajah, so his real tutor kept obscure. There is a possibility that after he had studied principles of Sharia law and reasoning, he self-studied books of Aristotle and selftutored by reading his books, as it is obviously seen on Aristotle great influence on him. No 
doubt, he is a great philosopher encircled by an obscurity and many questions. Did some writers mentioned describe him a reckless philosopher as? Did he join philosophy and theology as obvious in some of his books? Did he adopt Ash'ari school in creed, Waqifi or Mufawidh, etc.? The secret behind this obscurity is his trial to live with the common people while his inner was somewhere else in the world of elite. He accepted the common understanding of common people, but gave himself the right to go deep to understand the deep meaning of things such as who don't accept the shallow understanding. Ibn Rushd represents a class above the class of commons, but not scholars of theology such as the scholars of reasoning among the Mu'tazilah, Asha'irah, Matridiah, and those who run in the same circle and called argumentative who try to pursue, forsooth, that which is allegorical seeking (to cause) dissension by seeking to explain it.

Ibn Rushd is not easy to identify, once he is seen well informed of the sayings of (fuqaha) jurists, and in many occasions, he tries to weigh some sayings over others, or prefer an opinion to another opinion, using arguments. In some occasions, he talks about the Salafi School as a well informed and praises its trend in not trying to explain the names and attributes of Allah, but rather confirming them with befitting the dignity of Allah. In other occasions, he acts irrationally as call to arbitrate evidence similar to philosophers, and considers them origins in judging divinities rather than narrative evidences, and adopts the theory of oldness of universe as appeared in some of his books ${ }^{(1)}$.

\section{About this Research;}

Before beginning, I would like to introduce the following to the reader:

1- There should be among Muslims, consolidate of the source in knowing the Islamic creed, and adopting the source to look into any meaning of Islamic creed terms and should not be ignored, therefore to avoid the creed of the Muslim from any falsity, atheism or delusion.

2- It is not permitted to cripple the reason in the field of Aqidah (creed) or other fields because reason incurs liability, but reason should not exceed its function and cross its boundaries by jumping into corrupt imaginations and illusions as imagination and illusion are not valid base for true belief or knowledge.

3- Our call to the ones of source is proved by Islamic law clearly by narrated texts and the sound reason does not deny following the rule, which says: "The sound of mind reason- doesn't contradict intact narration".

4- If reason leads us to know Allah Almighty and Mohammad is His prophet, then how could be there any contradiction with what came in Quran and intact traditions of the prophet, or how would be valid to deny reports by Allah or His prophet arguing that they deny reason when the sound reason doesn't contradict these reports; this is an obvious contradiction to what reason led to!

5- Reason is light made by Allah in ones heart to uncover existing things and facts, and to understand what Allah and His prophet report. This is the function of reason. You cannot exceed by asking your reason to clarify to you what you like or imagine, but cannot reach, unless they are illusions and imaginations. As we mentioned before, neither illusions nor imaginations are valid base for valid knowledge of true belief. (2)

\section{Defining Reason}

(Aql means tie) It has said to reason a thing is to understand it or become understood. Reason is spiritual light by which one perceives essential and instinctual things and begins to grow since his being in the womb of his mother until reaching the maturity.(3) 
It is said to theoretical and reason evidences: Because they are perceived by reason, as man use his mind in his arranging, formation and organizing. In addition, the reason is called reason because it bound its owner to prevent him from falling in unwanted false creeds or hideous deeds. "Tie it i.e. "your camel" and trust in Allah". (4)

\section{Defining Narration}

Naql "narration" in Arabic means to transport thing from a place to another. Those who narrates tradition of the prophet "Ahadeeth" and narrate them referring to the sources.

Evidences from Quran and Sunnah are call (Naqli evidences), which means transferred evidences, or hearing (unwritten). They are also called reporting or Gnomic, they all carry the same meaning, they all refer to evidences reported on Quran and Sunnah or evidences brought to us by the people of Hadith and narrators.

\section{The explicit mind does not contradict intact Narration.}

The title should be the axial of our research and a base to start from in this study for opinions of Ibn Rushd in the field of divinities and its discussion to discern his schools clearly which is a difficult task indeed because reason have led us to existence of the Creator, and the validity of the message of his messenger whom he provided with miracles that prove his prophet hood of prophets after using reason and thinking . Ibn Taymiyyah says: (5) "The explicit mind never contradicts correct narration" Under this slogan, he wrote a book called: The agreement of sound reason with correct narration. Ibn Rushd may agree with this for a while, but at a stage in the middle he abandon this stream of thinking to return back to his illusion contradicting, and calling this school the schools of majority and commoners. On the other hand Ibn Rushd blames the scholars of reasoning and accuses them of spoiling and distracting Sharia concept for people. This attitude is not to criticize their attitude but rather for announcing this to common people instead of hiding. He accepts for scholars' interpretation, but not for commoners providing they do not announce their attitude because they have literal nature. Ibn Rushd lived this uncertainty, unclear in his creed and philosophy, which he himself called it: bringing agreement between Sharia and philosophy, or between wisdom and religion. He believed in his approach so in some occasions he attack Al Ghazali declaring their approach to commoners what he should only tell for scholars.

\section{Philosophy of Ibn Rushd:}

Nobody disputes that Ibn Rushd was a great philosopher. It was not easily possible to identify his thoughts as previously mentioned due to his obscurity. It's not just to accuse his intrepidity to announce his inner thoughts, but he decided not use his courage to announce and stand steadfast to them. He in some occasions was forced to cope with people against his beliefs especially after the torment he suffered by Sultan Mansour Ibn Abi Yaqub, Sultan of Muwahideen. His books were burnt and he was accused of atheism. It is said that the cause of that torment was his denial the presence of " $A$ ' $d$ " people who were mentioned in Quran in front of Cordoba. Despite the dispute about Ibn Rushd, but whoever studies his opinions testifies his depth and consider him as one of the most reputable Islamic philosophers in metaphysics and his trials to link philosophy with Sharia with his understanding. (6)

Ibn Rushd explained many books of Islamic and other philosophers. He criticized them and refuted their opinions, and he stood at reasoning science and did not admit their opinions, so he criticized Asha'ries', Mu'tazilies' and Maturities' and described them with 'controversialists who argue with falsity until the text subdue to their opinions and reasons". He decided to have his own path and launched his approach in philosophy, but had stumbled in some occasions. 
Some of his setbacks are:

He found some Quran verses contradict philosophy, so he had to interpret them into two different ways, one for the commoners and one for the elite. The literal for the commoners while the spiritual for philosophers. He even says more grave things: "As prophets receive inspiration and convey to commoners, philosopher are the prophet for the knowledgeable consequently it should make an agreement between science and religion, and scholars should join between wisdom and Sharia and work from Sharia what agrees with wisdom to make sure that their work is compatible with wisdom. One of his famous sayings: "right doesn't contradict right but agrees with, and testify to". (7)

It is obvious that this is a hazardous stumble, and even a fatal and unacceptable in Islam. It is a blasphemy against prophet hood status as it is a state for those chosen by Allah, and Allah chose them to convey the message to people and guide them to the right path since Adam to Mohammad, the Arab Hashemite the seal of the prophets. Allah says:" Muhammad is not the father of any man among you, but he is the messenger of Allah and the Seal of the Prophets ..." Al Ahzab 40.

Claiming prophet hood to anyone after Mohammad is a clear contradiction to this verse and furthermore to true tradition of the prophet. The prophet says: "I am the seal of the prophets, no prophet shall come after me" Ibn Rushd claiming prophet hood to philosophers is false and inroad. He even make them an elite class of prophets who had sent to elite people when he said: “... even philosophers; they are the prophets of preceded knowledgeable..." I renounce his understanding to the meaning of prophet hood when he allows himself to place non-Muslim Greek philosophers such as his master Plato Aristotle among prophets. Does his philosophy and thinking allow him to place such ancient or modern philosophers who were not Muslims among the prophets of Allah! (8) .

To return to Ibn Rushd sayings: "right doesn't contradict right but agrees with and testify to" is a true saying regardless of the intention of Ibn Rushd. We have already quoted saying of some investigators "'The sound reason doesn't contradict intact narration", and when dispute occurs between reason and narration there should be one of two things:

First: Narration is not true, misinterpreted or wrongly interpreted.

Second: The reasonable matter, which claims that narrations contradicts, is not obvious and not intact, but engulfed with suspicion or desires which diverted its reasonability and integrity. In other cases, the reason is sick or for sure unpurified, if the reason had been well and intact, it would not have contradicted intact narration in any field. This base is well accepted among fair wise people, and would not be questioned among whoever when looking into reason issues when having enough knowledge of narrations and is free from intolerance, vagary and bias Abul Waleed bin Rushd referred to this base in his book "Minhaj ul Adellah" in different sections while discussing some reasoning scholars' opinions in their weird interpretation which is distant from the spirit of Islam, and to answer their arguments against Islamic Sharia; some of his sayings in this regard:

"The extremist against Sharia among this stream of thinking are those who interpreted what they thought is not as the apparent meaning, and they claimed that the intended meaning is their interpretation. Allah mentioned these things which are allegorical to test his slaves and an examination to them"; then Abu Al Waleed says: "We seek refuge by Allah to think wrongly of Allah, but we say: the book of Allah came a miracle in its obviousness and clarity, then he says: He is away from the intention of Sharia the one who says of what is not allegorical is allegorical, and then he interprets it with his claim, and then call people to believe and adopt this interpretation, as they said in the verse of rising "Istiwa" on the throne, and other things they said that its apparent is allegorical. Abu Al Waleed refer to some verse of the attributes of 
Allah which were distorted by the scholars of reasoning who were then followed by many people in their distortion such as in the case of the verse of coming forth of the Lord in the Day of Resurrection "And thy Lord shall come with angels, rank on rank" and the attribute of love "Allah will bring a people whom He loveth and who love Him", and the attribute of mercy which appears in the saying of the prophet "The merciful are shown mercy by the AllMerciful", "Have mercy to those on earth, and the Lord of the heavens will have mercy upon you.", and the attribute of pleasure or satisfaction which is extracted from saying of Allah "Allah is well pleased with them and they are well pleased with Him" ,and the quality of satisfaction that was obtained from Allah, the Almighty, quote: "Allah is satisfied with them, and they are satisfied with Him"(Al Mai'da 119), and other qualities' texts that are mentioned in the Holy Quran and Sunnah, and which the heresiarchs and many philosophers highlighted on it the interpretation types which is far from the speaker's mean, it also took the people far from the right interpretation of the texts of qualities. (9) Abul Walid cites a wonderful example for this kind of people, he says "who interpreted something of sharia, and pretended that his interpretation is what the sharia means and declared this interpretation to the public, is like who took a medicine was prescribed by a good doctor to save people's life or more, then someone took this great combination medicine for bad mood that he had but didn't suit him , this which is not previewed except to the least of people, then he pretended that some of those medicines which the first doctor declared it in that general benefit combination medicine is not the medicine that is known to the people by the name that this name means, but he meant another medicine which this name may indicate through a far metaphor, then he removed this combination from the greatest medicine, and added the medicine that he thought is what the doctor meant instead of it, and said to the people that this one is what the first doctor meant, so the people used this combination medicine according to what this interpreter has interpreted, so it corrupted a lot of people's mood. Some people's felt that people's moods are corrupted because of this combination medicine, and decided to repair it through replacing some of its medicines by medicine other than the first one, so it exposed people to a kind of disease other than the first kind. Then a third one interpreted this combination other than the first and the second ones, this exposed people to a third kind of disease other than the above kinds. Then a fourth one interpreted other medicine than the above interpretations, so by the passage of time on this greatest combination, and the interpretations of people on its medicines, changed it and replaced it by others, it exposed people to many kinds of diseases until the purposed benefit has been corrupted by this medicine. This is the case of the difference occurring in by this way with sharia, So that every team of them interpreted the Sharia in a different way of other teams' interpretations, and pretended that it is the meaning that the owner of Sharia, until it split into many parts, each part is so away from its first position.

When the owner of Sharia (peace be upon him) knew that this is happening in his Sharia, he said that "my people will split into 73 group, all of them are in hell except one of them", (10) he means the one that followed the apparent Sharia, did not interpret it to an interpretation, and declared it to people. If you contemplate what is in this Sharia in that time from the corruption, which happened through this interpretation, you would see that this example is true, and the first people who changed this great medicine are the Kharijite, after them the Mu'tazila, then the Asha'ries people, and then the Sufis. And the same meaning to the end of his speech, it's really a correct and proper example if it didn't include only one thing; it is what came in the interpretation of Ibn El Walid to the quote which he cited, as he said: when he characterized the only group, who will survive from hell and win paradise" he means the one who followed the apparent Sharia and didn't interpret it to an interpretation and declared it to people. So we can understand from this weird interpretation that the abhorred interpretation - in Ibn Rushd's view, is the interpretation with not declaring it to public who are not scientists but it's a concept for private people, they may not follow the apparent Sharia when it is contrary to 
wisdom - in their point of view - they called it the reconciliation between Sharia and wisdom. The second concept: is a concept for the public, they are the people who are not scientists as before, their duty is to follow the apparent sharia before they deviate from it, they may not interpret but to inform about it. This is Ibn Rushd's philosophy in this issue, so he fell in an uglier mistake in what he thought is fault he found on the heresiarch as he pretend that the Islamic Sharia has two meanings; public meaning or philosophical meaning of wises, he claimed that both meanings are right, and purposed by people. He declared before that this claim is a changing for Sharia and corruption to people. Ibn Rushd is one of the public; the scholar title is not used for anyone, except the philosophers who sometimes they call them wiser. (11)

I don't know how this great philosopher did not know that the right can't be varied, but it's only one without any conflict, so what about the right and wrong?!

The situation of Ibn Rushd made me remember the quote of the Arabic poet: (12)

"Don't prevent people to do a behavior and do the same, it's a great mistake if you do"

But what Ibn Rushd has done is worse than what heresiarch has done especially in this situation, and this before we add his irony of the Sharia scientists and describing them as public. (13)

\section{The existence of Allah for Ibn Rushd:}

I couldn't find in what I've read for Ibn Rushd, a clear opinion denying the existence of Allah the creator, but on the contrary, we find that he draws signs of the ways to know Allah the almighty, and evaluates the intellectual evidences for existence of Allah, and refer to the evidences of the universe and human beings clearly, but as he split people in the concept of Sharia - as we said before -, he split them again in the field of induction by universe evidences for the existence of Allah, he says that: "the evidences for the existence of Allah, the creator, include these two types":

1- The evidence of protection

2- The evidence of invention

The evidence of protection is based on that the human shall think well and look around to see the protection, care of Allah and the uncountable Graces of Allah. Allah has created for him many things, but all the things on earth and skies, this appears in his Quote "He has subjected to you whatsoever is in the heavens and the earth; all is from Him." (Al-Jathiya: 13).

The evidences of creation was based on contemplating well to the entities and industries, which do not only indicate the existence of Allah, but also indicate his greatness, his ability and his loneliness, as an effect shows affection and a quality shows the great creator. Abul Walid sees that, for each of the evidences, a group of people understand it and specialize in its understanding and recognizing, he makes the evidence of protection a way of public as it is sensible, as well as he makes the evidence of creation as the way of scientists, as they increase what they know through feeling, by what they know through evidence, which could be done through looking and thinking, and contemplate in the kingdom of Allah and earth; and the reference of that in "Do they not look at the Camels, how they are made?, And at the Sky, how it is raised high?, And at the Mountains, how they are fixed firm?, And at the Earth, how it is spread out?", to induct the existence of Allah, his ability, and his wisdom to contemplate the secrets of these creatures, as this was in the best of their abilities than the public "On no soul doth Allah place a burden greater than it can bear"(Al-Baqara286). (14) Now let's listen to Abi El Walid when he guides the public to know the induction of the existence of Allah, the almighty, he says: 
The way that the Quran had called up for, and called us all because of it, is included in two kinds:

1- In the protection for human and creating everything for him.

2- Then what appears in the invention of the essences of things like invention of life in solid things, sensory perceptions and mind, so we can call this evidence of invention.(15)

Ibn Rushed sees that those two evidences are the evidences of Sharia, and then he says: "all entities in this universe are suitable and useful for the existence of human being, like the existence of sun, moon, plants, animals, rains, seas, air and fire. But also in the human organs itself an evidence for that the creator of the universe is almighty, wise, all knowing and gentle to his servants". So he continued in his wonderful speech and says: As all these entities was created from nothing, then there must be a wonderful creator, who had created this universe, has the ability to create, as those nothings are impossible to be Narrated from nothing to the existence by themselves, This Creator is Allah, Allah, there is no God but He, and there is no God except him". (16)

\section{The oneness for Ibn Rushd:}

As appeared before, Ibn Rushd cannot be blamed in the subject of proofing the existence of Allah, the Almighty. I am not saying that he is only sure of the existence of Allah but he is ready to convince others, who have doubts in this issue or who are not sure from the existence of Allah, the Almighty, by intellectual evidences cosmic signs through his excellent and powerful technique. As we saw before in the sections, let's listen to him while is showing us the evidences that comes through the an authentic hadith of the prophet Mohammed (peace be upon him) and the intellectual evidences, and analyzing this issue; as he proves that Allah, the Almighty, is one, eternal, according to these Quranic verses:

"Say, He is Allah, the One and Only; Allah, the Eternal, Absolute; He does not beget, nor is He begotten; he has no one unto him" (Al Ikhlas 1-4)

Ibn El Walid says: if you contemplate the word (No God but Allah), and believed the two meanings in it; they are acknowledging the existence of Allah, the creator, and denying the divine entity of others, is the real Muslim". He proved by his philosophical recognition, that Allah is the maker; He is the first creator; He made all things in universe by an order system and law; He created all differentiated entities through initial and eternal creation, and all at the same time. So Ibn Rushd sees that the first doer is only one, it is a self-oneness, as I cannot be extra on His being, which is at the same time His existence. (17) This means that the qualities are in the entity of Allah and united with it, and not added to it, we are going to explain it clearly later - if Allah wills -.What does Ibnel Walid wants from this (philosophical jargon), after he had proved the existence of God and His oneness according to his Quranic verses, and after he succeeded in interpreting the word " monotheism" through an ancestral interpretation, proved in it the Deism and divinity together accurately and wonderfully. Moreover, he declared that the real Muslim who believe in the oneness of Allah in His Deism and divinity. After all this, his philosophy refused to use except a torturous and closed way, which the philosopher has mingled with this issue, and that perhaps this mingle is an affection of the effects of Aristotle and his colleagues' philosophy, whom the philosopher studied their books and affected with them. They believe that the universe is old and eternal, and they prove other affection than Allah's in this universe as Orbits and others for independence. They resembled Allah by a king in a country, who gives the independence to others due to his need for them to cooperate with Him. (18)

God is far above the partner and the assisting minister! He is only one. 
Those philosophers, whom Ibn Rushd affected with their philosophy, believe that Allah has created only the first mind, and then the first mind created the second mind, and so on; it is a frivolous speech and full of blasphemy; and talking about Allah without knowledge. (19)

Ibn Rushd has involved in this believe as you see, and as will be shown in his talk. Then he plunged in this issue as long as the theologians plunged in it. Are Attributs obstine qualifies? On the other hand, they are the essence of the entity of Allah. As he decided that the entity of Allah, His existence and His oneness are words varies in their meanings, but their significance are the same. Allah is old because the as a one, former to any combination; and this Old One is absolute eternal. The Attribute of wisdom, ability, oneness and others of Allah are not obtained. (20)

It can be said: the qualities are the essence of entity, so the judgment is right, which means that the qualities cannot be far of the entity, as we can't imagine science without a scientist; or an ability exist by its own without an capable person; or a will exist by its own without someone has a will. Thus, and by this consideration, we can say: the qualities are the essence of the entity.

As well as, we can say that the quality is not the entity, so by other consideration, this judgment is also right; it is that the quality has a meaning, and the entity has a different meaning than the quality meaning. So on this consideration, the quality is not the entity; what was said in this issue will be said as: is the name the essence of the named or the unnamed? Therefore, by this meaning, the speech of Abul Waleed comes, as he says that the Attributes of Allah are not added to His entity, God knows best.

Abul Waleed is making such research, in case any new bid'a, which is unknown to the successors, has been released, as they hardly add to what the Quran and Sunnah indicate, but they believe that Allah is characterized by the perfection qualities like knowledge, almighty, mercy, and others of entity and actual qualities. They do not ask are these qualities the essence of entity or different from the entity. (21) This is the right method; it indicates the depth of the successor's knowledge, their accuracy and their estranging from staginess and talking about Allah without knowledge.

They are well known by that they do not transcend the Quran and Sunnah in Allah's demands, fearing from talking about Allah without knowledge and to plunge in the facts of His entity, qualities and his names, or to sway the imagination, this is a very significant matter. As no one can characterize Allah knows more than Allah, and no one of His creatures can characterize him, knows more than Mohammed the prophet (peace be upon him), whom Allah gave the permission to characterize him and to inform people of what got down to him from Allah, and the qualities of Allah which got down to him. As they estrange from staginess, they are not looking forward to recognize the facts of qualities of Allah and his names, believing that the creature should not know everything about the creator, whatever he gets of knowledge and intelligence; because the creatures knowledge are limited. (Knowledge it is only a little that is communicated to you) (Al Esraa: 85. and it cannot be measured by any kind of measurements, (there is nothing whatever like unto Him, and He is the One that hears and sees (all things). (Ash Shoura :11). (knowest thou of any who is worthy of the same Name as He?) (Mariam: 65), (And there is none like unto Him). Al Ikhlas: 4). We can note that Ibn Rushd can forgive himself, but not forgive others, as we saw before, he can give himself the freedom to interpret whether he nibbles this if it released from others, and call it bid'a. 
For equity, equity is from faith; this behavior is deemed a bid'a for all, even for Abul Walid himself. Generally, the student, who study Ibn Rushd books, can find that he provides intellectual evidences and evidences from Mohammed (peace be upon him) in his discussion of theology, which shows his wide knowledge, his wonderful ability, his extraordinary intelligent.

\section{Knowledge for Ibn Rushd:}

Abul Walid says in some of his books: "the qualities that the Quran declared, which characterized the creator of the universe, are the qualities of perfection which exist in the human beings, to what he said: the Quran showed us the evidence of knowledge, in His verse: (Should He not know, He that created? And He is the One that understands the finest mysteries (and) is well-acquainted (with them)) (Al Molk: 14). This evidence is that the creatures indicate; in accordance with its parts order; and parts of them were created for the other parts; and as they all correspond to the purposed benefit of this creature; so they are not made by nature, and also they are not made by accident, but it shows that there is a creator organized what is before the purpose before the purpose, so he should be a scholar for it. For example, if the human looks to a building; then he recognized that the footings were made for the wall and the wall was made for the ceiling, then he assures that the building was existed by a scholar of construction.

Abul Walid says that " if you contemplate in the entities parts, its order, its organizing, and the connection between its parts, and the need of its parts to the other parts, you will recognize that such creation was made by an Omniscient and wise creator. This is the evidence, which Ibn Rushd has mentioned, his style prevents the pretension completely, and that the universe was created by accident, or was created by nature. As the explicit mind and the correct instinct, refuse the release of this weird creation from a nature, not more the thing itself, or one of its qualities. The thing cannot create itself, whether the quality of the thing is affiliated to the thing; because it exists by this thing, as known by philosophers". Then he continues in the quality of knowledge and says:

"It's an old quality, as Allah can't be characterized by this quality one day, but we shouldn't deepen in this issue, so they say: what do they say?". Then he discussed with the heresiarch about their bid 'a that they created as usual; it is their quotation "Do Allah know the things happened by an old or a new knowledge?!!, to the end of their speech, which shows no appreciation to Allah the creator, then Abul Walid says : "this is not mentions in Shari 'a. Otherwise, it was declared, it is that Allah knows the new things at the time of doing it; as He said: (Not a leaf doth fall but with His knowledge) (Al An'am 59). (22)

Thus Abul Walid acknowledge the knowledge of Allah is comprehensive, and that he knows things before its being, and how it will be, " he is the knower of everything, how not?, while he is the creator and the supreme fashioner. This is the concept of the knowledge of Allah for Muslims forbear or progeny, estrange from the staginess and resembling of resembles, and the speech of the heresiarch who talks without knowledge. The Muslim nation was plagued by this sect whatever affliction.

\section{Ibn Rushd's attempt to find a compromise solution in the issue of oldness of universe,}

Ibn Rushd discussed the current dispute between who said that the universe is a new creation after it was nothing and the philosophers who said that the universe is old and eternal but they confess that it is a creation. Ibn Rushd says that the conflict here is verbal, which means that it is not essential, there are two ends and a mediator, they all agreed on the two ends, and they are:

Firstly, there is only old one, the first, which there was nothing before.

Secondly, on the other end, there is universe; it is new for all, but the conflict is on "is it new or old? The philosopher continues in his discussion saying "in reality, the universe is not really 
new, Or really old, because the quote that the universe is really new is wrong because the universe cannot be perished by nature, or its material cannot be perished, the real oldness has no reason but the universe has reason.

Then the universe is new if we considered it as it has a reason from Allah, and that it is old if we considered that it was existed in immemorial time without lax in time. The summary is that the universe for Allah is new, and in the creatures' views is old". (23) Thus, the philosopher Ibn Rushd has finished his hard discussion. Many good philosophers have confused in this issue, and talking in this issue considers obtrusions, as another one of the moderate philosophers said: it is enough for human to say two sentences with understanding and Jurisprudence, they are:

1- Allah created all things and he is the originator and restorer.

2- Anything except Allah is new after it was nothing, and that is enough.

The suspicion of Ibn Rushd is in his hesitation in this issue in two things:

1- That God will still really creative

2- The material of universe cannot be perished.

The reply for the first suspicion, is: Allah has the meaning of divinity before the creation was created, has the title of creator before He creates anything, He is the provider before He creates the provision and the humans He provides, which means that He has the perfection qualities from eternity and forever. His creation does not give Him new Attributes he has not before. It cannot be Decent that He, the almighty, has a new Attribute, which He characterized by it before; because these Attributes are perfection Attributes and by losing some Attributes means shortage quality and it is not right to think that He obtained perfection after He has not.

This is clear in the personal qualities, whether the actual qualities like creation, giving lives, taking lives, presenting, revelation, anger, and satisfaction, even if these cases and actions are renewed and happens in different times such as what came in Hadith of intercession, the prophet Mohammed peace be upon Him) says : "today my God has angered an anger, no one has angered like it before, and no one will do after", as this renew and happening don't mean it wasn't exist; we can not say that it happened and it wasn't exist before. Don't you see that the one who talks today and did not talk yesterday? We don't say that talking happened to him, but in case he talks we say: he is already talking, and in case of his silence we also say that he can talk, as well as who is able to write, we say that he is a writer and in the other case we also say that he is a writer. Therefore, Allah the almighty is creator, provider, giver of life, giver of death and giver, before He creates his creation and servants whom He provide, give, give them life and give them death; because he is able to do that since eternity. He wasn't lacking any quality or unable to do anything of these actions, but He is able to do anything. I hope this can give the demander of truth the knowledge of God and a failed attempt to know God well because of our limited knowledge and personal inability (knowledge it is only a little that is communicated to you) (Al Esraa 85), (they shall not compass it with their knowledge) (Taha:110), (Nor shall they compass aught of His knowledge except as He willeth) (Al Baqara :255). This was the reply of the first of the two suspicions that made Ibn Rushd hesitated in if the universe new or old?. Now let's reply on the second suspicion, The material of universe cannot be neither perished, nor executed, and this is the evidence that the universe is old. Here, Ibn Rushd is trying to conclude from the survival of the parts of universe and its imperishability the universe is eternal. The answer: it is true that some creatures cannot be perished but remain alive by the will of Allah, we can reply on this survival by two answers:

Firstly: to be imperishable doesn't mean to be eternal, since there is no connection between imperishability and eternality. (24) 
Secondly: the survival of the eternal creations is not by its own will, but Allah who gives it the eternity like paradise and its people, and hell and its inhabitants. The only One whose eternity is a personal quality is Allah, no one can share him his eternity, as well as no one can share him any of his qualities, even if the names of some qualities are the same, He is the first, nothing exist before Him, and $\mathrm{He}$ is the last, nothing will exist after Him. It is so clear for truth demander, and we thank Allah.

\section{The quality of live, oldness, and will according to Ibn Rushd's view}

Ibn Rushd proves some qualities of Allah, on the Asha'ries method, despite the violent attacks that sometimes he does upon them.

From the Attributes, that Ibn Rushd proves: the quality of life, will and oldness. He proves these Attributes by mental evidence supported by the evidences from Sunnah, although the dependence for him is on the mental evidences like heresiarchs, but he sees the dependence on the evidences of Sunnah is the method of public, he means by the public who are not philosophers.

He says - proving these qualities after talking about knowledge- : the existence of the qualities of life, will, and almighty appear clearly in the quality of knowledge, as life, will and almighty are the conditions of knowledge, the provision shall Narrate from judgment to the invisible, and what they say is right, say this correction is considered equity from Ibn Rushd. Although his rough discussions about the Asha'ries and Mu'tazila, he confesses with their favor in what they did right, because the right is the pariah of the theist, he must take it where he find, even if from the heresiarchs. (25)

We can find that the philosopher Ibn Rushd contradicts with himself a lot, as we sometimes find him do situations, which he said before those are wrong, in the interpretation and calling for public meanings, and the special meaning for some texts. This is not weird as the contradiction is a common quality for philosophers except for what deviated and who deviated but they are little. Abul Walid is not a bid 'a of philosophers, this makes it easy for us, it was said before: "if it generalized, it becomes easy" (26).

\section{Talking for Ibn Rushd}

Ibn Rushd's method to prove the quality of talk, is the same one he took to prove the quality of life, will and almighty, it's the induction by the proof of knowledge quality, as the talk according to Ibn Rushd's philosophy not more than an act the speaker do to indicate to the listener the knowledge that he has, and all actions are the same. The weirdest is his quote: "there might be in Allah's talks which addressed to scholars, the heirs of the prophet by evidences, so by this argument the scholars believed that Quran is the talks of Allah". Ibn Rushd has widened in the concept of talks until he added in the named Allah's talks the philosopher's talks about that Allah addressed his talks to them through evidences.

Abul Walid's situation in this issue is so weird and dangerous; he objected the Asha'ries who believes in both the mental and nominal talks, as the mental is real talks of Allah, whether the nominal is indicant about it or interpretation to it. Therefore, the Quran, for the Asha'ries, is not the real talks of Allah but indicant to the real talks of Allah, which is the mental talks, so that we should protect it to the last talks known for them. Abul Walid didn't comply to this school of thought perfectly, and didn't refuse it completely, but at the same time he opposed the Mutazila as they didn't prove any mental talks, but declare that Allah's talks was created, and according to them, Since Allah is speaker, therefore He is creator of talking. According to them, Quran is a creature of Allah's creatures, their point of dispute is to declare that it's a creature or not. (27) 
The Mutazila thinks to declare to the public, because in the doctrine issue the public and the philosophers are the same. While the Asha'ries think not to declare, except for education, as if it is a doctrine for the philosophers not the public. This situation is similar to Ibn Rushd's situation in the differentiation between the public and the philosophers in some of duties and beliefs - as seen before- but he select for himself another method in this issue, as we referred before, and as will be shown later, if Allah wills. That is what we meant by: 'his situation is weird and dangerous". As for Sunnah people who contented themselves by what the successors of this nation, the companions and the followers of successors were, who think that Allah talks really through his own method, which we do not know, as we shall not compass him with our knowledge (they shall not compass it with their knowledge.) (Taha: 110), (Nor shall they compass aught of His knowledge except as He willeth) Al Baqara: 255. They don't engage in how He talks, they also don't engage in how all his qualities. As their belief in Allah is without reason, so their belief in His qualities is the same including the quality of talk? As the quality of talk is in the entity, and the talk about some of the qualities is like the talk about the other some of qualities.

The Quran is All Allah's words like all Allah's talks it is not a creature, Allah has told us in His Quran that It is His talks. He says: "If one amongst the Pagans ask thee for asylum, grant it to him, so that he may hear the word of Allah; and then escort him to where he can be secure." (at Tawba 6). So there is no doubt that the talks that this pagan have to listen to be secured is the holy Quran, which is in hearts, and written on bills, so that we shall be invoked and say Allah has said: (this and that). His words have no end, he said:(Say: "If the ocean were ink (wherewith to write out) the words of my Lord. Sooner would the ocean be exhausted than would the words of my Lord, even if we added another ocean like it, for its aid") (Al Kahf : 109). (28)

This is the belief of Ahlussunna "Sunni people" and their view in the Holy Quran, they are the best in this nation, though the testimony of the prophet Mohamed (peace be upon Him), he says: the best people are my nation, then who follows, then who follows". (29) To be good requires the truth of belief and its truth is a must, as they believed in the owner of the message, the prophet Mohammed (peace be upon Him), they took from Him their religion and belief. If we believe that Mohammed peace be upon him has informed Allah's message completely in origins of religion and its branches, and believe that the companions has understood what they have been informed by prophet Mohamed (peace be upon him) a right and comprehensive understanding, and bore the trusteeship of informing to their successors and actually informed them, if we believe y this belief, we have to believe the good is in following them, because they are right and they are on the straightway; and opposing them means making bid'a in Religion with pretending that religion is not done yet but needs additions, modifications and improvement. All these are dreadful challenge to Allah's testimony to his prophet (peace be upon him) and his successors that He has perfected their religion and completed the favor of Islam upon them, (this day have I perfected your religion, completed My favor upon you, and have chosen for you Islam as your religion) (al ma'da: 3). This testimony has released at the end of prophet Mohamed (peace be upon him)'s life and it was released in the farewell hajj publicly in the greatest muster happened in the Islamic history.

All what I mean by this digression is that the correct, in this issue and other issues of religion including the research around the Quran, is what the ancestors of this nation from companions and successors followed, and all what oppose what they followed is untrue (the right is only one). Those are the three groups in this issue, we do not know if there is a fourth one. But we surprised by a weird quote for Ibn Rushd during our study to his books, in his definition of talks, we mentioned it before, but he ended it by saying: " that we made the letters of the Holy 
Quran, and its veneration is because it refer to what created for Allah, and the meaning that it is not a creature". (30)

\section{Discussion of Ibn Rushd's opinion:}

We can summarize the philosophy of Ibn Rushd, in this issue, in two points:

1- His definition of talks that it is an act the speaker do to the end of his quote.

2- Pretending that the letters of Quran has two types, one is made for us, and the other is created for Allah. The one, which is made for us, indicates the created term and the uncreated meaning.

My comment on the first point that: they are nonsense words, which are refused by Arabic language and reality. in Arabic language the talks is an action; the grammarians say in defining the talks: is the compound word which is useful in situation); which means that it is the pronounce term, actually people can differentiate between the talks and the action. I think that's enough in explaining this point as it is clear enough as I think. The second point: Ibn Rushd's claim that there are two types of letters of Quran is dull in our opinion. Any way he fell in the same mistake of making the bid 'a; he criticized in the heresiarch. He didn't stand for the apparent Shara' as he calls for and as it is necessary for any Muslim. Then:

It's better for Ibn Rushd to apply the rule he always mentions in his research, it is (the scholar is not entitled to apply humanitarian considerations on issues related to divinity), but unfortunately he violated it and didn't comply with it. It is noted that Ibn Rushd has opposed the heresiarch in their situation, in the issue of the qualities of Allah, and denounced their interpretation and stressed on denouncing them. His opinion was to let the texts of qualities the same as apparent, and calls for that clearly, of course, it is right, but he changed this in his method of defining talks and sided with the Asha'ries method, which says Quran is created with proving the mental talks on it. He also added to their opinion, saying that the Quran has two types of letters, one of them, was created for Allah and another one was made for us indicates to the created letter. As you see, this is a so weird situation, but it is a so dangerous slip, affects the faith of its owner, May God helps us.

\section{Ibn Rushd's" Averroes" opinion in the Attributes of Allah prove.}

Deactivated qualities people used to interpret the Attributes of Allah by different types of interpretations, as in their point of view violates the reasonable things; they used to entitle qualities' evidences by these names:
a- imaginary
b- embodied
c- visceral

They pretend that the proof needs likening and embodiment, but it is a dull pretension, which did not based on a scientific basis. It is only an inherited pretension, which the heresiarch inherits from each other; it can be released from ignorance. The likening or embodiment is an excessive on the proof, to prove the knowledge of Allah, it is not necessary to liken Him with his creatures, as the knowledge of the creator is supreme not like the knowledge of the creature. The knowledge of the creature shall fit his status as something brought to being like him. It must be limited cannot be compassed by information, and is exposed to forgetfulness, inattention and surprising, and it is not eternal, as the quality dies with the death of its owner. The knowledge of Allah is Supreme and Old, He knows everything, he can't forget surprise. It's eternal like Allah. Proving the qualities of Allah is forbidden, He Said: (there is nothing whatever likes unto Him, and He is the One that hears and sees (all things)). (Ash Shoura: 11), (and there is none like unto Him) (Al Ekhlas :4), (but they shall not compass it with their knowledge). Taha: 110, (knowest thou of any who is worthy of the same Name as He?") 
(Mariam : 65). What we say in the quality of knowledge are the same in the rest of the mental and actual qualities. Thus, it is proved for the classifier that proving is different from likening. Abul Walid has used these titles, which are mentioned above, on the Mothbita as people used to do .It was expected from Abul Walid to act as more seeing and fair, and put everything in its position, and to give the title to the right group, and call the group, who really proved the qualities of Allah, as require, as Muthbit, and to the group, who interpreted and distorted them, as an interpreter, and to the group, who likened the qualities of Allah by the qualities of his creatures, is who makes likening.

We have proved before that muthbita are not likening or embodying, but their method is in the middle between likening and frustration, as we said before, the group of likening has exaggerate in proving the qualities of Allah, so they proved it through their belief that they are like the qualities of creatures, pretending that they can't understand the qualities of Allah unless they understand the qualities of creatures. For them, the ability of Allah is like the ability of creature; His will is like theirs, and also His love and satisfaction. The Mu'attila has denied all or some of Allah's qualities through the pretension of the Tanzeeh "disclaiming", by believing in that the proving of the qualities of Allah leads to likening. Therefore, the Sunnis followed the right way. They proved what Allah has proved for himself and what Mohamed (peace be upon him) has proved for Him of the qualities of perfection without likening or embodying as He said (There is nothing like unto Him). Abul Walid has eulogized this method in many situations in some of his books. Nevertheless, he thinks that it suits the public without the scholars, because they do not stop at this point but they have to sink in philosophy or to study a lot to discover the facts that the public do not know. They must not declare it for public. If Abul Walid followed a specific method in his judgment on people, it would be easy for us to understand his judgments and then discuss him, but it is too hard to achieve. Whereas you find him discuss the names and qualities in the ancestors' method, and prove the qualities and follow the apparent Shari 'a, you find him, taking the floor of heresiarchs, interpret and deny the proof. I think that among the philosophers, you can find him live in abstruseness, and I think that you would not understand anything they say. If you pass by a group of jurists, you can find him among them discussing them by arguments. Maybe stayed in Muhaddithin seats to be resembled by them. As he said:

(Resemble ifyou are not like them, the resembling by men is achievement)

The most significant quality for Ibn Rushd is that he thinks himself flying in the sky of philosophy with a group of wise people leaving the public with their simplemindedness - in his view-

\section{Ibn Rushd proves the resurrection by intellectual and Narrative evidences;}

Abul Walid says whereas the shari'a has agreed on its existence, and the scholars found its evidences, but the Shari'a contrasted in the quality of its existence, but in fact, they did not contrast in its existence. Ibn Rushd indicates that the resurrection is not a point of conflict between the Shari'a of heaven, or the wise people and scholars, but it was agreed on in the two fields' shari'a and philosophical - but they had contrasted in two issues:

1. Is it only spiritual, or spiritual and physical together? Then he gets the evidence that this issue is based on the spiritual agreement in this and the agreement of all to get the necessary evidences for this". Thus, Ibn Rushd declared that the Narrative evidences were taken from the shari'a of heaven, so the intellectual evidences agreed on that the human has two types of happiness:

- secularism

- another related to the after life 
Then Ibn Rushd analyzed this issue saying that: for all, this is based on basis, which is known by all, it is:

a- The human being is nobler than all creatures.

b- If it is clear that, each creature is not created for nonsense, but is created for a required action, which is the seed of his existence. Allah called the attention to this meaning about His creation in His book, he said: (Not without purpose did We create heaven and earth and all between! that were the thought of Unbelievers! but woe to the Unbelievers because of the Fire (of Hell)!) (sad: 27). He also said while praising his servants who knows the required purpose of being: (Men who celebrate the praises of Allah, standing, sitting, and lying down on their sides, and contemplate the (wonders of) creation in the heavens and the earth, (with the thought): "Our Lord! Not for naught hast thou created (all) this! Glory to Thee! Give us salvation from the Penalty of the Fire.) (Al Emran: 191).

The existence of the purpose of creation is clearer in human beings than other creatures, so Allah had called our attention to this in his verse "Did ye then think that We had created you in jest, and that ye would not be brought back to Us (for account)?" (Al Mo'menoun: 115), and said : (Does Man think that he will be left uncontrolled, (without purpose)?) (al Qeyama: 35), and said: (It would not be reasonable in me if I did not serve Him Who created me, and to Whom ye shall (all) be brought back.) (yassin: 22), and said: (I have only created Jinn and Human to obey Me.) (Ath Thariyat: 56). Then Abu El Walid said, while showing the agreement between the Narrative and intellectual evidences for resurrection, whereas the revelation has said in all the shari'a that the soul is eternal, and the evidences of scholars had proved that, the souls become free of physical lusty feelings after death, so if it was good, it becomes better and free of lusty feelings, and if it is bad, it becomes worst and feel sorry when it leaves the human body. Allah says: (Lest the soul should (then) say: 'Ah! woe is me! in that I neglected (my Duty) towards Allah, and was but among those who mocked!') (Az zomar : 56). Thus, Abul Walid decides that the resurrection, as shown in Shari 'a, and as the intellectual and Narrative evidences showed. (31) Nevertheless, this subject did not freed from conflict in it, so we can summarize these conflicts in the following:

1. is the existence after death is the essence existence, which means that the existence, which is full of bliss, is united with the existence before death, but differs in

2. The physical existence is different from this existence, they are only united in the name of the physical existence, with differing facts, inferring by the quote of Ibn Abbas:" there is nothing in life exists in the afterlife except names). Abul Walid thinks that this second opinion is better.

3. Some of philosophers think that the after world is only spiritual; he mentioned it only to express the meaning. It is weird that Ibn Rushd sees that the owners of this opinion have many evidences but he did not mention any of them. Ibn Rushd contradicts with Imam Ghazaly in his opinion this issue, as he thinks it important to believe in the resurrection of bodies, and judge by atheism for who deny this and believe in the resurrection of souls. AlGhazaly has expiated some philosophers such as Kindy, Faraby and Avicenna, an addition to their belief that Allah only knows the things totally and not partly, and their belief in the oldness and eternity of universe.

Thus, Ibn Rushd appeared to be permissive, but contradicting in this issue for its importance. It is not only permissive and contradicting, he interprets it in a so far way, as he considers it as a juristic deduction, he says: the truth in this issue is as anyone can think about, but not to deny the origin as a whole, or to deny the existence". This way of belief requires the expiation of his owner as the knowledge of the human being by the existence of this case is known by all through Shari 'a and minds. 
The summary of Ibn Rushd's opinion in this issue is to believe in the afterlife, and that there is resurrection, but whether the resurrection is for souls or bodies, it is no important according to his opinion, and everyone has to believe according to his juristic deduction.

However, the truth in this issue, which Ibn Rushd had failed in it, but failed in the claim that it depends on juristic deduction, the right is that it depends on the text, and of course, juristic deduction cannot be with text. As the Holy Quran and Sunnah are so clear, and shows that resurrection is for both the soul and body together. So let us listen to the following verses, as it reprobate the human being forgetting that Allah created him from a sperm, and ask who can give life to dry bones? (Doth not man see that it is We Who created him from sperm? Yet behold! He (stands forth) as an open adversary! In addition, he makes comparisons for us, and forgets his own (origin and) Creation: he says: "Who can give life to (dry) bones and decomposed ones (at that)? Say, "He will give them life Who created them for the first time! For He is well versed in every kind of creation! "The same Who produces for you fire out of the green tree, when behold! Ye kindle therewith (your own fires)! (Yassin : $77: 80$ ), and the following verse which describe the day of judgment (The Day that We roll up the heavens like a scroll rolled up for books (completed), even as We produced the first Creation, so shall We produce a new one: a promise We have undertaken: truly shall We fulfill it.) (Al Anbiaa: 104), It is He Who begins (the process of) creation; then repeats it; and for Him it is most easy. To Him belongs the loftiest similitude (we can think of) in the heavens and the earth: for He is exalted in Might, Full of Wisdom. (ArRoum: 27).

If we move to Sunnah, we will find that it assures the resurrection of body, which leaves no place for doubt or argument (my nation will be resurrect with white faces, hands and legs), and his hadith my nation will be resurrect at the Day of Judgment without shoes or clothes and as they were created). The indication in the first Hadith is so clear, because the description, by faces, hands and legs, is for the body and of course to the soul!

In the second Hadith, its indication on the purpose is not less than the first one, because the four descriptions cannot, except for the body, and of course, it includes the soul.

I think the issue is clear now , it doesn't need more evidences than the holy Quran and Sunnah, and the mind can understand that, as the foresaid verses connected between the starting of creation and the resurrection (It is He Who begins (the process of) creation; then repeats it; and for Him it is most easy) (ArRoum : 27). (32)

\section{The extract:}

As it is mentioned above,

It has proved through the narrative and mental evidences that the resurrection is physical. It was proved that it is an issue of text and not juristic deduction.

The denying the physical resurrection, is a denial to the Holy Quran and Sunnah, and out of mind requirements, the denial of the Holy Quran and Sunnah is considered an infidelity.

\section{Predestination for Ibn Rushd}

Undoubtedly, the belief in the predestination is a significant side of the Islamic creed; this belief has a clear effect on the human being and his acts, and in its situation from the acts that surprise the human being in this life. The belief must be based on the right meaning of predestination, and this right meaning cannot be exist except in the divine revelation which is represented in the Holy Quran and Sunnah, the source cannot be replaced by other or shared by any other source as an essence source. 


\section{The meaning of fate and destiny and which if them is first}

The scholars differed concerning which of them is first, the fate or destiny

The quote, of Abu Hatem Ar Razy and other scholars, reassures us and the evidences confirm it; its extract is that destiny is the destination, and fate is execution, the evidences that Abu Hatem has mentioned is the meaning of Allah's verse : ( (So) hath been decreed that matter whereof ye twain do enquire.) (Yosef: 41). its meaning is, the emptiness, and (And when the Prayer is finished, then may ye disperse through the land) (El Gomaa: 10) (or ended it), the fate and destiny is like the trailer, who have to draw the dress before making it, and it can be increased or decreased; tightened or widened; and if he had finished it, it's destiny; then it can't be increased or decreased like the fate and destiny. There are many other definitions, some of them versus them and put destiny before fate. (Allah knows best)

However, this or that, Allah already knows his creatures and writes their fates, and created him as he wrote his fate, the action of humans cannot change his fate, as well as the accidents and disasters. The servant is His creature with his soul, body, qualities and actions; He controls his growth by his actions and will. If Allah wants the servant to do something, he gives him the ability to do so. The fate happens by the ability of the Creator, so we cannot deny the perfection of Allah's ability, there is nothing in universe works without the will of Allah, and we cannot deny the ability of the servant, which is given to him by Allah to do the required actions. This is the method of the nation of Sunnah and Quran in this issue, and is what the ancestors have followed; it is in the middle between the determinism and fatalism. It will be shown later (if Allah wills).

This issue is from the hardest issues in Shari'a, as Abu El Walid says, for the existent contradiction between the evidences, which leads people to split to three parties, two parties and one between them.

\section{The first party:}

\section{The Determinism ( Al Jahmeyyah);}

Al Jahm Ibn Safwan heads them; this party believes that the human is obliged in his actions of Good and evil, the actions are attributed to the humans metaphorically, exactly as the inanimate objects. The inanimate objects differs from the human only in shape; like if we write someone read, stand and sit, is the same when I say the camel moved, the sea billowed and the trees paid off. The reason in this belief is their fear to fall in the same mistake of the fatalism, as they think that the human creates his action. As will be shown later (if Allah wills).

The determinism forgot that the servant is affected; and said that he is obliged and he is not able to choose; but they missed that he is affected and effective. (33)

\section{The extract of this:}

This doctrine is based on denying the assessment, retribution and punishment for actions, which means that the messengers and the divine book revelation is nonsense; it is a denied doctrine and refused by mind and Sharia':

By mind: concerning retribution, it is not rational to give the worker a wage for a work he did not do by his own selection; it is attributed to him metaphorically.

However, the punishment, it is not fair to punish the worker for a mistake he did under obligation, without his choice, on the other side, it makes the revelation of invitation and intimidation in Holy Quran and Sunnah, and the warnings of messengers are nonsense.

The is the extract of the belief of the determinism 
The second party: the fatalism mutazila:

This party thinks that servants create their actions in His will and with His will.

\section{Their point of view}

They said so, when they saw the servant do and leave with his own choice, and that the Shar'a proved the idea of retribution for righteous deeds, and punishment for sins, they also noticed the difference between the natural movement of hand and the quivering movement of hand, as the first is done in choice, and the second is done in compulsory actions. In addition, we can recognize the difference between the one who is going up to lighthouse and the one who is falling down, as the first is the will of the human, but the second is not his will but Allah's. The people noticed these actions and movements of humans, so they contemplate him as a doer but they missed that he is reactant. Therefore, they pretend that the human is the one who creates his feeling by his own ability before the interference of Allah's ability. There is no one shares Allah in His divinity and creation. They missed that the human with his body, soul, will and ability is a creature of Allah, Allah who creates for him the ability to work and the will of work, and makes him a doer and has a limited will, until He attributes the work to the new created ability, and to become the causative in same time when the deeds is related to Allah, as the addition of the creature to the creator. Both parties are so far from each other, as the servant is obliged there and a creator here. Both parties have lost their way, and the righteous became lost between them, but the people of Sunnah had found the right way, and their doctrine became the best

\section{The retribution for Al Ash'ari}

Abul Hassan El Ash'ari tried to get a compromised solution between the determinism and fatalism, however, he was unsuccessful; as he made the focus of assessment is retribution, the retribution is the deed, but it is the will, which is gained upon the deed. They put themselves in this strait, in order not to say that the human is the real and independent doer, exactly as at the fatalism, or to say that he is obliged and has no will, as the determinism said, but they did not say any thing new, they use the same method, which is the obligation, and the difference between them and the determinism, is literal but not essential. Their method is more ambiguous, the earning of Asha'ry is considered from narrators, and the narrators of philosophy are three:

The retribution forAl Ash'ary

The statuses for Abi Hashim

The instance of Natham

We have discussed the retribution for Ash'ari; its extract is that the human is not the doer in fact, but Allah creates the action when he has the will to do action. We can say that it is a sophisticated compulsory, or hidden.

The statuses for Ibn Hashim: it means the moral qualities, which are specifically proved by Abu Hashim than the other Mutazila through his denial of the meaning qualities, which means that he denies the qualities of knowledge, ability and will, and other qualities. Then he proves that He has the knowledge, ability and will. Therefore, these beings are the statuses of Allah.

The instance of Natham: is a slide, Natham (Mutazila)is the only one who did this slide than others in Mutazila; it's that Allah has created all his creatures together, as it is now, like plants, animals, mountains and seas. He did not make the creation of Adam prior to his sons, Allah made them included in each other. The advancement and delay is only for tangible things, rather than its existence. 
Natham pretended his claim affecting with the philosophers, who owns existence. It is an instance, there is no one achieved it before.

\section{The extract of Ibn Rushd's opinion}

Ibn Rushed says in the summary of his long research, in the issue of fate and destiny: "as the arrangements and order of reasons, requires the existence of a thing; so the knowledge of the reasons of something is the knowledge of the existence or nonexistence of such thing. Therefore, the knowledge of reasons is the knowledge of what exists and what doesn't exist of it, in any time, so Subhan Allah for the knowledge of an inventory including all its reasons. And these are the keys to the unseen in His verse (With Him are the keys of the Unseen, the treasures that none knoweth but He) (Al Ana'am :56)

What described before makes it clear how it is acquisition for us, and how all our acquisitions are accompanied by prior fate and destiny.

This is what the Sharia meant by altogether in these verses and Hadith which are thought to have contradictions, and its generalization is specified by this meaning, denied the contradiction, with this all suspicions in this issue are solved, I mean the contradicting mental evidences. I mean that, as the existent things are by our will, then its existence is by both of them together, I mean by our will and the surrounded reasons. If we attributed the actions to one of these, then the advancement suspicions are true. (34)

Ibn Rushd has mumbled about the doctrine of the Holy Quran and Sunnah in this issue. He is not following determinism, fatalism and retribution for Al Ash'ari. He proves that the human has ability and will, and acknowledge that things exist through a prior fate and destiny. He said that they must be gathered together, the destiny and fate. He calls them the external reason whether the will of the human is the internal reason, and all things exist only by the will of Allah, the two issues must exist together. This means that the human do the actions through his own will, ability and selection, but him, his will, his ability, and the tool he used or his mind, all are a creation of Allah.(Is there a Creator, other than Allah?) (Fater: 3).so the relation between actions and the human is like the relation between the cause and the reason because the will and ability of the human is the reason of the existence of such actions, Allah had made a reason for everything. This relates to Allah as the relation of the creator and the creature. This is the method of the people of the Quran and Sunnah. Therefore, Ibn Rushd must be happy for this succession in this hard issue as he described by himself in his book "evidences curricula in doctrines of boredom". (36)

After this summary and our comment on it, let us recite some of the Quranic verses, which Ibn Rushd referred to, to see how it agrees and relate them with each other, so all doubt will disappear -(if Allah wills).

The first group of verses that he referred:

(Let him who will, believe, and let him who will, reject (it)) (Al Kahf: 29). ((With profit) to whoever among you wills to go straight) (At Takweer: 28). (Then shall every soul be paid what it earned) (Al Baqara: 281). (It gets every good that it earns, and it suffers every ill that it earns) (Al Baqara: 286). (This is because of the (unrighteous deeds) which your hands sent on before ye) (Al Emran: 182).

The set of verses of book and Sunnah, and their meanings which indicate that human beings do any action by his own will, and selection. 
What confirms this meaning is that mad people cannot be asked for the actions, because he does not do it by his own will or a considerable will.

The second group: (And We have created for them similar (vessels) on which they ride.) (Yassin : 42). (It is Allah Who made your habitations homes of rest and quiet for you; and made for you, out of the skins of animals, (tents for) dwellings, which ye find so light (and handy) when ye travel and when ye stop (in your travels)) (An Nahl: 80). (Allah has created you and your deeds) (As Saffat: 96).

This group and other texts of revelation indicate that, even if the human is the doer of his actions, in fact and not metaphoric, and has a will and ability to do the action, then both of them are the creation of Allah, and they are only reasons to give the human the reason to do action of, as Allah had created the cause and reason together. As the human do his action with his own will, but this action is also a creation of Allah, such as the ship is made by human beings, but Allah who has created him, his hand and his will, as well as, the houses, leathers which are mentioned in the second group, I hope Allah assist us.

By this way, the verses that appear to be contradictory and non-contradictory in fact are agreed on. If the first group indicated that, the human do the actions by his own will, to be rewarded for the good deeds and to be punished for the wrong deeds. The second group indicated that the human and his actions creatures of Allah, and He is the only creator.

\section{The secret of Fate:}

As long as we go through this significant study, we have to say something to try to answer a significant question, which has been frequented in minds. The question is consists of two parts, the question is: if Allah willed from a man the sin, and didn't will the obedience, so why he punishes him for what he didn't will from him? In addition, why he did not will for this man the obedience like others?

The answer of the first part of the question: we had discussed before the final principles for the people of Sunnah that guidance and misguidance, obedience and sin are by the will of Allah, but the man is a cause for its happening, and his responsibility for his actions is another final principle from this side. Therefore, the rule that the philosophers agreed on that the finals are not contradicting even if it appeared contradictory due to our limited recognition.

Therefore, we have to believe all these finals and not to deny anything from them even if we did not know anything about them, because fate and destiny are related to the qualities of Allah: such as his knowledge, wisdom and will. AS we failed to know all about the qualities of Allah, we also failed to know any about the secret of fate. The secret of fate is that Allah guides and misguides, gives happiness and sadness, gives death and life, and others, all that for a wisdom no one knows except Him, so here is the secret! He is the all-knowing and the ever wise, Subhan Allah the all-knowing, and knows the number of everything. There unknowing of the secret of fate gives no harm to the belief of the man, because it is not possible, on no soul doth Allah place a burden greater than it can bear. The thing that gives it Harm is to put provisions based on his inability, and act in a wrong way, such as denying some final principles of fate, and mixing contexts with each other.

The answer on the second part of the question: we will refer to the quote of Ali "May Allah blesses him" "the fate is the secret of Allah so we can disclose it". (37) Therefore, we failed to answer on this, as it is a secret of fate: (Why Allah willed the obedience of Zaid and make him succeed in it, while he did not will it from Amr and did not make him succeed in it?). The 
answer is in Allah's verse: (He cannot be questioned for His acts, but they will be questioned (for theirs) (Al Anbiaa: 23). Undoubtedly, the owner can act freely in his property, it is not necessary to be a right act, to let others recognize the wisdom and reason for His actions. No one is entitled to object on his act if he did not know the secret of it.

If we saw an owner of a garden, his garden contains many kinds of trees, and we find him cuts one, and organize other, and find him neglect another one, so is anybody entitled to object on these different actions? The answer is of course not. Because we do not know what is the reason for what he have done or left. So this is the meaning of the quote of Ali "may Allah bless him": (the fate is the secret of Allah, we cannot disclose it), it means not to try to disclose it to recognize the hidden secrets, because it will be with no result. In addition, the one who tried to know what is not possible because of his attempt is like:

A one who hit a rock to break it, so no harm happened to it, but he broke his head.

\section{From the fruits of believing in fate:}

The one who has a right faith in fate can go through the permissible reasons, so he depends on Allah in the success of the exerted reasons and not on the reasons itself. As well as, Prophet Mohamed peace be upon Him, he hid in a cave on the day of migration from Mecca to Madina. This is considered as instructions from Him to the nation to accept reasons and go through it. He did so to get rid of the polytheists' evil, he didn't desire to survive for the reason of survival, but he depended on Allah, The Almighty, Allah said (he had no more than one companion: they two were in the Cave, and he said to his companion, "Have no fear for Allah is with us) (Al Tawba: 40). This means that he trusts Allah, which made him felt safely and peacefully, because of this special accompaniment, but he did not neglect the reason as result of this dependence and trust in Allah. Then we find him again go through the reason in Badr war, as we found him setting the army as a material reason he should go through, then he went back to the pole which is beaten in land of war, so he prayed to Allah and continued in praying to Allah to help them to win the war. He also urged hid friends to sell and buy. There are some of his friends who work as farmers and merchants engaged in selling and buying. Therefore, this is the right meaning of dependence and it a fruit of right believing in fate. (So glory to Him in Whose hands is the dominion of all things: and to Him will ye be all brought back.) (Yassin: 83).

\section{CONCLUSION}

We have successfully, (by the assistance of Allah), prepared this research, in which we discussed the situation of the philosopher Ibn Rushd from the Mind and Narration. We found, in this research, that Ibn Rushd is remedying the reconciliation between the Shari 'a and wisdom, and his rough discussion for the heresiarch interpretation, which the heresiarch focused on in the contexts of qualities, to follow what are similar in contexts, for interpreting it, and no one can interpret it except Allah. We confirmed, in this research, on the necessity of uniting the source of the Islamic doctrine, which is the divine revelation, to not to be shared by any other source, neither the philosophy nor the heresiarch, nor any other measurements.

After all, it is stupidity to say that Sharia did not show the issues of doctrine. Philosophy is necessary to know details, and this is not true because the doctrine issues are the heart of the research, and is the significant reason of sending messengers and revelation of the Holy Quran. It is impossible that the Sharia neglect showing this request, which is the most important of all, without a clear analysis; to not to let people go to another source to know from it, in the time; the branches of Shari'a became clear, and it showed Sunnah and its moralities. It showed us how to perform ablution and its nullifications, and how to perform Teamed, and others branches. 
The one who follow the verses of Quran and read many of the prophet's (peace be upon him) Quotes (Hadith), and studied it and understood it, will recognize that the doctrine will let anybody leave going through philosophy, and leave the sophistry of the heresiarch.

At the end, many thanks to Allah, the creator of all people.

\section{References}

Disclosure of Methods of Evidences in the Doctrines of Milla, Ibn Rushd, p 21.

Belief in Fatalism and its Effect on Human Behavior by Dr. Abdul Karim Zidan, p 17.

Dictionary of the Glory, Majduddin Al Fayrouzabadi, v, Aqala.

Sunan Attermithy, book of slaughtering, unite 2011.

Statement of reasonable and frank approval of Saheeh Al-Maqoul for Ibn Taymiyyah, p 89.

Summarizing; Beyond Nature, Ibn Rushd, p 6.

The final decision of communication between Wisdom and Sharia, Ibn Rushd, $\mathrm{p} 61$.

Ideal materialism in the philosophy of Ibn Rushd, Dr. Mohamed Amara, p 13.

Disclosure of Methods of Evidences in the Doctrines of Milla, Ibn Rushd, p 28.

Sunan Attermithy, Abu Isa Attermithy, H: 2640.

Statement of reasonable and frank approval of Saheeh Al-Maqoul for Ibn Taymiyyah, p 108.

He is Abul Aswad Addo'aly,

Ibn Rushd between the West and Islam, Dr. Mohammed Amara, p 51.

Explanation of Attahaweyyah doctrine, Ibn abil Izz Al- Hanafi, p 215.

Statement of reasonable and frank approval of Saheeh Al-Maqoul for Ibn Taymiyyah, p 113.

The final decision of communication between Wisdom and Sharia, Ibn Rushd, $\mathrm{p} 80$.

Idealism and materialism in the philosophy of Ibn Rushd, Dr. Mohamed Amara, p 63.

Previous reference, $\mathrm{p} 77$.

Called Divine Flood Theory.

Disclosure of Methods of Evidences in the Doctrines of Milla, Ibn Rushd, p 32.

Previous reference, $\mathrm{p} 36$.

The final decision of communication between Wisdom and Sharia, Ibn Rushd, $\mathrm{p} 91$.

Disclosure of Methods of Evidences in the Doctrines of Milla, Ib Rushd, p 45,

Statement of reasonable and frank approval of Saheeh Al-Maqoul for Ibn Taymiyyah, p 136.

The final decision of communication between Wisdom and Sharia, Ibn Rushd, p 96.

Explanation of Attahaweyyah doctrine, Ibn abil Izz Al- Hanafi, p 219.

Summarizing; Beyond Nature, Ibn Rushd, p 47.

Statement of reasonable and frank approval of Saheeh Al-Maqoul for Ibn Taymiyyah, p 142.

Sahih Al Bukhary, Mohammad EbN Ismael, book of virtues of Companions, Hadith3449.

Disclosure of Methods of Evidences in the Doctrines of Milla, Ibn Rushd, pp. 55-56.

The final decision of communication between Wisdom and Sharia, Ibn Rushd, pp. 98-99.

Statement of reasonable and frank approval of Saheeh Al-Maqoul for Ibn Taymiyyah, p 184.

Belief in Fatalism and its Effect on Human Behavior by Dr. Abdul Karim Zidan, p $45 .$.

Statement of reasonable and frank approval of Saheeh Al-Maqoul for Ibn Taymiyyah, p 108.

The final decision of communication between Wisdom and Sharia, Ibn Rushd, p 105. 
Disclosure of Methods of Evidences in the Doctrines of Milla, Ibn Rushd, pp.70-72.

Explanation of Attahaweyyah doctrine, Ibn abil Izz Al- Hanafi, p 223.

\section{Index:}

The Holly Quran.

Belief in Fatalism and its Effect on Human Behavior by Dr. Abdul Karim Zidan, Journal of the College of Islamic Studies, 1974, Issue 8, Baghdad.

Disclosure of Methods of Evidences in the Doctrines of Milla, Ibn Rushd, Achieving by Dr.Mohamed Abed Al-Jabiri, Bureau of Arab Unity Studies, Beirut 2001.

Summarizing; Beyond Nature, Ibn Rushd, Achievement of Dr. Othman Amin, Library of Mustafa Al-Babi Al-Halabi, 1st edition, 1998.

The final decision of communication between Wisdom and Sharia, Ibn Rushd, Study and Achievement, Dr. Mohamed Amara, Darrel Maaref Cairo, First edition, 1997.

Ibn Rushd between the West and Islam, Dr. Mohammed Amara, Dar Nahdet Misr 2004.

Statement of reasonable and frank approval of Saheeh Al-Maqoul for Ibn Taymiyyah, Achieving of Sheikh Mahmoud Qatriya, Dar Al-Nawader, Damascus, 2012.

Dictionary of the Glory, Majduddin Al Fayrouzabadi, House of Scientific Books, Beirut. Lebanon first edition, 1972.

Fathulbary fi Sharhi Sahih Al Bukhary, Ibn Hajar Al Askalani, Dar Al-Nawader, Damascus, $4^{\text {th }}$ edition, 2012.

Idealism and materialism in the philosophy of Ibn Rushd, Dr. Mohamed Amara, House of Immortality Heritage, Cairo 2002.

Explanation of Attahaweyyah doctrine, Ibn abil Izz Al- Hanafi, Achieving of a group of scholars, Library of Islamic office, Damascus, 1975.

Sunan Attermithy, Abu Isa Attermithy. Achieving of Shu’aib Alarnaout, Global Message Library, Beirut, 2007. 